\title{
Health Education About Clean and Healthy Living Behavior (PHBS) To Increased Knowledge of School Age Children: Systematic Review
}

\author{
Nur Ridha Sasmitha, Hasnah, Eny Sutria. \\ UIN Alauddin Makassar, Indonesia \\ Corresponding author: nurridhas@yahoo.co.id
}

\begin{abstract}
Background: In school-age children, the most common problem is clean and healthy living behavior, one way to improve clean and healthy living behavior by providing health education.

Purpose: This study aimed to identify and analyze available scientific evidence about the effectiveness of health education on improving the knowledge of school-age children.

Methods: This research method uses quantitative descriptive design with systematic review approach. Literature search through database: Google Scholar, Garuda Portal, Indonesian Scientific Journal Database and International Journal of Social Science and Humanity with structured research questions using keywords using the PICO method (Patient, Intervention, Comparison of Intervention and Outcome).

Results: There were 83 articles identified, only 6 that met the inclusion criteria were analyzed using Duffy's Research Appraisal Checklist Approach.

Conclusion: Health education with the media is very effective in increasing the knowledge of school-age children about PHBS, the media obtained from a variety of literature, namely education with snakes and ladders, quiz games, pocket book media, video media, poster methods, and dance video methods. Health Education with the media is very effective in increasing the knowledge of school-age children found in this review to be used as an intervention in health education.
\end{abstract}

Keywords: Health education, Knowledge of school age children, Clean and Healthy Living Behavior. 


\section{Journal Of Nursing Practice}

http://thejnp.org

ISSN: 2614-3488 (print); 2614-3496 (online)

Vol.3 No.2. April 2020. Page.279-285

\section{BACKGROUND}

School-age children both preschool, elementary school, junior high school and high school are a child's age that is very different from adulthood. In this period there were many health problems that determine the quality of children in the future. School-age children are a critical age group because at that age they are susceptible to various health problems. Health problems faced by school-age children are basically quite complex and varied (Dewi, 2015).

The most common problems of school-age children are clean and healthy living behaviors, developmental disorders, behavior disorders and learning disorders. Then epidemiologically, children's health problems related to the spread of environmental-based diseases among school children, the risk of health problems in children due to environmental pollution from various development activities in Indonesia is still high or increasing and the problem that must be considered is that shaping behavior in school-age children is usually related to personal and environmental hygiene such as good and proper brushing of teeth, habit of washing hands with soap and personal hygiene (Annisa and Nur, 2017).

The inculcation of PHBS (Clean and Healthy Life Behavior) values in primary schoolage children is very important, considering the health problems that often occur in primary school-age children are related to PHBS (Edyati, 2015). PHBS in schools is a set of behaviors practiced by all school members on the basis of awareness as a result of learning, so as to prevent disease, improve health and play an active role in creating a healthy environment.

According to WHO, every year around 2.2 million people in developing countries, especially children die from various diseases caused by lack of safe drinking water, poor sanitation and hygiene. In addition, there is also evidence that adequate sanitation services, safe water supplies, waste disposal systems and hygiene education can reduce mortality due to diarrhea by $65 \%$, and other diseases by as much as $26 \%$ (MOH RI, 2013).

According to the Ministry of Health of the Republic of Indonesia, the regencies / cities that have a PHBS policy nationally in 2018 amounted to $70.62 \%$, which has exceeded the Restra 2018 target of 70\%. A total of 12 provinces have reached $100 \%$, namely West Sulawesi. Gorontalo, Central Kalimantan, Bali, Banten, DI Yogyakarta, Central Java, DKI Jakarta, Riau Islands, Kep. Bangka Belitung, Lampung and Bengkulu. While in the province of South Sulawesi has not reached the target of $100 \%$ with a percentage of 95.83\% (Ministry of Health, 2018).

To improve hygiene and healthy behavior can be done by providing health education where education can improve health behavior and help prevent disease. Education influences what will be done which is reflected in knowledge, attitudes and behavior. The level of education influences awareness of the importance of health for oneself and the environment that can drive the need for health services (Nuraeni, 2012).

School-age children are easily motivated and their competencies are enhanced including aspects of knowledge, attitudes and behavior in the health sector, so that they can potentially be agents of change. It is expected that with school-age children's health education they have sufficient knowledge so that they are accustomed to applying clean and healthy living behaviors in their daily lives (Annisa and Nur, 2017). The results of the study Ridha Abduh, et al (2016). about the effectiveness of comic media on knowledge and attitudes about washing hands in elementary school students reveals that for health education to be more interesting and easily understood by children, the role of the media in health education is very important. 


\section{Journal Of Nursing Practice}

http://thejnp.org

ISSN: 2614-3488 (print); 2614-3496 (online)

Vol.3 No.2. April 2020. Page.279-285

Related research was also conducted by Ratnaningsih, (2017). Educational media are essentially educational aids. tools used by educators in delivering educational / teaching material. According to experts, the senses that channel the most knowledge into the brain are the eyes. Approximately $75 \%$ to $87 \%$ of human knowledge obtained is channeled through the eyes. While the other $13 \%$ to $25 \%$ channeled through other senses. From this it follows that visual tools make it easier to convey and receive information or educational material (Notoatmodjo, 2003). To increase knowledge about Clean and Healthy Behavior (PHBS), it must eliminate unhealthy behavior by providing a learning about clean and healthy living behavior by using media games that make children interested

Health education using the media is widely used to improve the knowledge of schoolage children, besides health education with the media is easy to do and interesting media and can be applied among school-age children, in this study, the author wants to discuss health education by using media to increase children's knowledge school age from various published literature.

\section{OBJECTIVE}

This study aimed to identify and analyze available scientific evidence about the effectiveness of health education on improving the knowledge of school-age children.

\section{METHODS}

Journal search sources in this study are Google Scholar, Garuda Portal, Indonesian Scientific Journal Database and International Journal of Social Science and Humanity, articles published from 2015-2019, intervention journals that use health education media that can increase the knowledge of school age children, is an efficient intervention based on research results and easy interventions.

\section{RESULTS}

Based on the results of a research article search, obtained several journals that discuss health education media that can increase school-age knowledge, research articles that fit the researcher's theme are 83 articles and based on inclusion criteria and the Duffy's Research Appraisal Checklist Approach sheet, 6 journals obtained including the Supporior Paper category (Score 205-306). The author takes the article in terms of the applicability of the intervention and in accordance with the inclusion criteria that have been set, namely articles in 2015-2019, Fulltext articles that fit the topic, there are ISSN / DOI or Volume is a journal of health education intervention in school-age children, a journal about health education which uses media, methods or games for children that can improve the knowledge of school-age children, languages used in Indonesian and English, journals published in Southeast Asia. Health education includes education with snake ladder game media, education with game quiz, education with pocket book media, health education with video media, education with demonstration method with the help of poster media, and counseling with dance video media.

\begin{tabular}{|c|c|c|}
\hline Intervention & Number of Articles & Presentation (\%) \\
\hline Media Snakes and Ladders & 1 & $16,67 \%$ \\
\hline Media Game Quiz & 1 & $16,67 \%$ \\
\hline Pocket Book Media & 1 & $16,68 \%$ \\
\hline Video Media & 2 & $33,3 \%$ \\
\hline Poster Media & 1 & $16,68 \%$ \\
\hline Total & 6 & $100 \%$ \\
\hline
\end{tabular}




\section{Journal Of Nursing Practice}

http://thejnp.org

ISSN: 2614-3488 (print); 2614-3496 (online)

Vol.3 No.2. April 2020. Page.279-285

\section{DISCUSSION}

1. Health education with snake ladder game media

The results obtained are 1 journal that uses health education about PHBS with snake ladder media to increase the knowledge of school-age children conducted by Annisa Nurhidayati, Nur Hilal (2017). Based on the results of health education research snakes and ladders game media that there is an increase in the average (mean) score of knowledge before and after being educated with snakes and ladders games with an average pretest score of 34.2 increased to 38.5 on the average score posttest. In line with the research of Afif Hamdalah (2016) proves that ladder snake game media is very effective in efforts to improve knowledge, attitudes and practices, on dental and mouth health, this is because snake and ladder games as educational media can increase the excitement in the learning process so that it does not cause effects bored.

Snakes and ladders media can be used in health education to increase students' knowledge about PHBS. The snake ladder game model is basically the same as the regular snake ladder game, but the advantage of the snake ladder game as a health education media is that there is knowledge about PHBS in schools through pictures on the board (beberan) as well as questions on the board and the answers on the answer cards as well as the meaning or meaning of the snake ladder media. For example in the picture of a ladder then a negative behavior or event changes into a negative behavior or event that changes into a positive behavior or event, if you do not want to suffer from stomach pain then you must wash your hands, as well as the meaning or the opposite meaning with the picture of a snake. (Nurhidayati, 2017).

2. Health education with Game Quiz

There is 1 journal that uses health education with Game Quiz to improve the knowledge of school-age children conducted by Tri Ratnaningsih (2017). Based on the research results obtained Wilcoxon hypothesis test results obtained a significant value of $0.003<0.05$, which means that there is an influence of the game quiz on increasing knowledge about PHBS in 4th grade elementary school students at SDN Carat 1 Gempol Pasuruan, the results of the study were supported by research from Mochammad Setyo Pramono and Astridya Paramitha (2011) using electronic games shows that, electronic game media can increase students' knowledge about Clean and Healthy Behavior (PHBS) with the results showing an increase in knowledge after being treated in the form of electronic games, the value of knowledge increases in unfortunate cities whose level of knowledge about PHBS which used to be $88.51 \%$ to $97.81 \%$.

According to researchers Game Quiz is a form of game or mind where players (as individuals or in teams) try to answer questions correctly. Interactive Quiz Game is an application that contains subject matter in the form of questions or questions that allow students to improve their insights and knowledge about learning material independently. Game quiz acts as a source of information which according to Notoadmodjo (2007) sources of information will affect the level of knowledge of someone who if a person gets a lot of information then he tends to have broader knowledge.

3. Health education with pocket book media

There is 1 journal that uses health education with pocket book media to improve the knowledge and behavior of clean and healthy living carried out by Mutmainah Farida Hanif, Mury Ririyanty, Iken Nafikadhini (2018). Based on the results of the study it was found that there were better knowledge differences when after the intervention of the PHBS pocket book at school. In line with Eliana and Solikhah's 


\section{Journal Of Nursing Practice}

http://thejnp.org

ISSN: 2614-3488 (print); 2614-3496 (online)

Vol.3 No.2. April 2020. Page.279-285

(2012) research on the influence of nutrition pocket books on the level of Nutrition knowledge in grade 5 students of Muhammadiyah Dadapan, Wonokerto Village states that the effectiveness of the Nutrition pocket book is based on the level of nutritional knowledge between before and after with the mean value before being given pocketbooks 71,33 and the mean after being given a pocket book 91,07 means that there is an influence of a pocket book on increasing nutritional knowledge in children.

Pocket book is one of the health promotion print media which has advantages which include long-lasting, covering many people, the cost is not high, can be taken anywhere, facilitating understanding and increasing the passion of learning Kholid (2014). According to the author the use of media PHBS pocket book is very good to use because it is practical in its use which is easy to carry anywhere.

4. Health education with video media

There is 1 research journal that uses health education with video media conducted by Mulyadi, M.Isra, Warjiman, Chrisnawati (2018) entitled the effectiveness of health education with video media on the level of knowledge of clean and healthy behavior, based on the results obtained $0.001(\mathrm{p}=0.001<0.01)$. This means that there is a significant influence before and after health education is given with video media to increase knowledge of clean and healthy behavior. This study is also in line with research conducted by Edyati (2015) that counseling on personal hygiene health with video media has an influence on the knowledge and personal hygiene attitudes of SD 1 Kepek students, this can be seen from the value of knowledge $p$ of 0,000 ( $p=0,000$ $<0,05)$.

Health education with video media is aired and captured by involving various senses, such as vision and hearing. The more senses are used, the easier it is to enter information.

5. Health education with demonstrations with the help of poster media

There is one journal that uses health education with demonstrations with the help of poster media conducted by Dwi Nurlailani, La Dupai, Putu Eka Maiyana Erawan's research entitled the influence of public health in increasing knowledge, attitudes and behaviors of clean and healthy life of students in fifth grade of public elementary schools 12 Poasia is based on the results obtained by researchers that there is evidence of differences in knowledge after being given an intervention for 21 days with health education provided by child health groups using demonstration methods with the help of poster media can increase knowledge.

The research that has been conducted shows that the respondents who have received intervention in the form of PHBS demonstrations by child health have increased from $74.5 \%$ to $95.7 \%$ which are included in the sufficient category. In line with Fitriani's research (2011) on the influence of peer education on clean and healthy living behaviors (PHBS), there were differences before and after being given peer education interventions on respondents' knowledge. Based on the results of further analysis it can be concluded that there are significant differences in respondent knowledge after being given peer education better than before peer education was given to the intervention group ( $\mathrm{p}$ value 0,000 alpha $=0.05$ ).

Health education about PHBS that has been provided through KELI to respondents using the demonstration method influences changes in the attitude of the respondents so that they experience an increase before and after the intervention. The knowledge they gained was able to bring up an understanding of themselves that they needed and had to do clean and healthy life behavior both at school and at home. In addition, the 


\section{Journal Of Nursing Practice}

http://thejnp.org

ISSN: 2614-3488 (print); 2614-3496 (online)

Vol.3 No.2. April 2020. Page.279-285

change in the attitude of the respondents after getting health education due to the demonstration method used is quite pleasant for the respondents so that it facilitates the process of receiving information about PHBS.

The existence of child health is sufficient to help respondents in determining attitudes so that some of the respondents were able to respond and appreciate what the child health teaching (peers) about PHBS. For example, there were several respondents who said that they had started to invite and teach their younger siblings and friends both at home and at school about some PHBS indicators such as hand washing and garbage disposal.

6. Health education with dance video media

There is one journal that uses health education with dance videos conducted by Moh Arip, Cembun, Desty Emilyani's research on strategies to improve knowledge, attitudes and skills towards clean and healthy life, based on the results obtained that the average value of students' knowledge prior to intervention is 3.42 30-8 students, while students' knowledge after the intervention is 3.87 out of thirty-eight students. Statistical analysis results obtained $\mathrm{p}<0.05$, which means that there are significant differences in knowledge before and after counseling using "PHBS kerasa video" on the habit of washing hands with soap "

Conventional counseling has been applied often to improve students' understanding of PHBS but the results are not significant enough. In addition, one-way counseling tends to make students feel bored so that there are some students who still remember the counseling message. Therefore, efforts that can be applied to improve students' understanding of PHBS in Sembung Primary School in Narmada are the traditional Sasak dances called by Rudat. Rudat dance video is claimed to be able to increase students' understanding of PHBS because it is a potential culture. It is also considered to be able to attract the attention of students so that it is expected to increase students' understanding of PHBS counseling (Culture \& Tourism, Mataram Agency, 2011).

The dance in this video is a traditional dance from Lombok called Rudat. The potential of Rudat dance as a medium of information for students is very large because its forms such as dance, music and one more person accompany with the lyrics about PHBS, especially relating to Handwashing with Soap (CTPS) then information what is delivered to students is very obtainable. In connection with Rudat Dance, it has the potential as a medium of information and counseling.

\section{CONCLUSION}

Based on the results of research from 6 articles it can be concluded that health education with the media is very effective in increasing school-age children's knowledge about PHBS is education with snake ladder media, education with game quiz, education with pocket book media, health education with video media, education with the demonstration method with the help of poster media, and the dance video method. The sixth education is recommended for use because the technique is simple, does not require a lot of tools and materials, is easy to reach as well as interesting methods and media and can be applied among school age children. 


\section{Journal Of Nursing Practice}

http://thejnp.org

ISSN: 2614-3488 (print); 2614-3496 (online)

Vol.3 No.2. April 2020. Page.279-285

\section{REFERENCES}

Annisa. (2017) Pengaruh Pendidikan Kesehatan Tentang PHBS Dengan Media Permainan

Ular Tangga Dan Ceramah Terhadap Pengetahuan Siswa Sd Negeri Limpakuwus Kabupaten Banyumas 2017.

Dewi W.R,S., \& Muhibuddin, N (2015) Pengaruh Penyuluhan Kesehatan Dengan Metode Ceramah Dan Penggunaan Leaflet Terhadap Pengetahuan Dan Perilaku Hidup Bersih

Dan Sehat Pada Siswa Sd. Jurnal Sain Med Vol. , No. 1, 30-35.

Departemen Agama, RI. (2014). Al-Qur'an dan Terjemahnya.

Departemen Kesehatan, RI. (2013). Riset Kesehatan Dasar (Riskesdas 2013). Jakarta Departemen Kesehatan.

Dwi Nurlailani Dkk. (2016). Pengaruh Kesmas Cilik Dalam Meningkatkan Pengetahuan, Perlaku, Dan Sikap Perilaku Hidup Bersih Dan Sehat Murid Kelas V Sekolah Dasar Negeri 12 Poasia Kota Kendari Tahun 2016. Jurnal ilmiah Fakultas Kesehatan Masyarakat Universitas Halu Oleo.

Edyati, L (2015). Pengaruh Penyuluhan Kesehatan Dengan Media Video Terhadap Pengetahuan Dan Sikap Personal Hygiene Siswa Sd Negeri 1 Kepek Pengasih Kulon Progo. Jurnal Keperawatan Stikes 'Aisyiyah. 3-19.

Fitriani, D. (2011). Pengaruh Edukasi Sebaya Terhadap Perilaku Hidup Bersih Dan Sehat (Phbs) Pada Agregat Anak Usia Sekolah Yang Beresiko Kecacingan Di Desa Baru Kecamatan Manggar Belitung Timur

Kementrian Kesehatan RI. (2018). Profil Kesehatan Indonesia; Jakarta.

Ketut Swarjana (2017). Ilmu Kesehatan Masyarakat Konsep Strategi Dan Praktik. Andi: Yogyakarta.

Kuswana, WS. (2013). Taksonomi Berfikir. Bandung: PT Remaja Rosdakarya

Listyarini, A.D. (2017). Penyuluhan Dengan Media Audio Visual Meningkatkan Perilaku Hidup Bersih Dan Sehat Anak Usia Sekolah. Jurnal Stikes Cendekia Utama Kudas. 112-117.

Mulyadi Dkk. (2018). Efektifitas Pendidikan Kesehatan Dengan Media Vidio Terhadap Tingkat Pengetahuan Perilaku Hidup Bersih Dan Sehat. Jurnal Keperawatan Stikes Suaka Insan.

Mutmainah F.H. (2018). Efektivitas Buku Saku PHBS Di Sekolah Meningkatan Periaku Hidup Bersih Dan Sehat. Jurnal Kesehatan.

Notoatmodjo, Soekidjo. (2010). Promosi Kesehatan Dan Ilmu Perilaku. Jakarta : Rineka Cipta.

Nuraeni, A. (2012). Hubungan Penerapan Phbs Keluarga Dengan Kejadian Diare Balita Di Kelurahan Tawangmas Kota Semarang. [Tesis Ilmiah]. Depok: Fakultas Ilmu Keperawatan. Universitas Indonesia.

Proferawati, Rahmawati. (2012). Perilaku Hidup Bersih Dan Sehat. Yogyakarta: Nuha Media.

Pramono, Mochamad Setyo dan Paramita, Astridya. (2011). Peningkatan Pengetahuan Anak-anak tentang PHBS dan Penyakit Menular melalui Teknik KIE Berupa Permainan Elektronik.

Shihab, M. Quraisy. (2002). Tafsir Al-Misbah : pesan, kesan, dan keserasian Al-Qu'ran. Volume 6. Jakarta : Lentera Hati

Tri Ratnaningsih. (2017). Efektivitas Game Quiz terhadap Pengetahuan tentang PHBS pada siswa kelas 4 SD. Jurnal sain med 